\title{
Patrycja Malicka \\ Gra z romantycznym afektem w Mariaszu Artura Daniela Liskowackiego
}

\begin{abstract}
Malicka Patrycja, Gra z romantycznym afektem w "Mariaszu" Artura Daniela Liskowackiego [Playing with romantic affection in Artur Daniel Liskowacki's Mariasz]. „Przestrzenie Teorii" 27. Poznań 2017, Adam Mickiewicz University Press, pp. 299-316. ISSN 1644-6763. DOI 10.14746/pt.2017.27.19.
\end{abstract}

The aim of the article is to show the connection between affection theory and romantic concepts of emotions (mesmerism and melancholy) in Artur Daniel Liskowacki's 2007 novel Mariasz. By way of introduction, the author presents in brief the most important research on affective turn conducted in Poland and around the world, and also shows the possibilities of affective reading. The next part of the article is an interpretation of Mariasz. What is more, affection theory, as it is used in the novel, helps us to describe the ambiguous network of relations between the characters more fully and clearly, who experience similar affections, despite the temporal distance between them (romanticism and modernity). By analyzing Liskowacki's novel we can identify the current relevance of the Romantic tradition in Polish literature after 1989, which is far from its martyrological connotations. Romanticism becomes a reference point for contemporary times, and original dialogues from that epoch allow the emotional nature of humans immersed in contemporary times to be described in full.

Zdaje się, że zwrot afektywny na dłużej zagości na scenie współczesnej humanistyki. Jedną z przyczyn popularności tejże tematyki jest fakt, iż idealnie wpisuje się ona w nowoczesny model teorii literatury żywo zainteresowanej problemami do tej pory marginalizowanymi. We Wprowadzeniu do publikacji Emocje w kulturze z 2012 roku Małgorzata Rajtar i Justyna Straczuk, zarysowując rozwój badań nad emocjami, zaznaczają, że ,jeszcze w 1970 roku antropologia emocji była praktycznie nieznana”, natomiast szesnaście lat później w artykule podsumowującym ostatnie publikacje dotyczące badań nad emocjami - The Antrophology of Emotions - Catherine Lutz i Geoffrey White zamieścili ponad 194 pozycji amerykańskich antropologów dotyczących tej właśnie tematyki ${ }^{2}$. Swoisty emotion boom zaowocował powstaniem ośrodków badawczych i stowarzyszeń specjalizujących się $\mathrm{w}$ tematyce badań nad emocjami. Teoretyków literatury, w odróżnieniu od antropologów, w kategorii afektu interesowała najbardziej jej płynność, niemożność dookreślenia (jak opisać afekt, który po opuszczeniu sfery prekognitywnej zmienia swój charakter i staje

${ }^{1}$ Emocje w kulturze, red. M. Rajtar, J. Straczuk, Warszawa 2012, s. 7.

2 Tamże. 


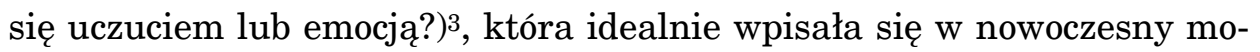
del teorii literatury porzucającej modele linearne i dychotomiczne na rzecz modeli nielineralnych i syntaktycznych (koncepcje „sieci” - Latour, „pola” - Bourdieu, „środowiska” - Braidotti) ${ }^{4}$.

Afektywność to bez wątpienia kategoria niezwykle nośna pozwalająca łączyć odmienne gałęzie humanistyki (psychologię, socjologię, historię, antropologię), a także umożliwiająca interpretowanie sztuki w zupełnie nowy sposób (relacja czytelnik - dzieło sztuki, głębsze spojrzenie na relacje międzyludzkie, afekty związane $\mathrm{z}$ danym przedmiotem czy miejscem, wpływ afektów na pamięć) $)^{5}$. Zwrot afektywny uruchamia ścieżki teoretyczne inspirowane „psychoanalitycznymi teoriami podmiotowości, postrukturalistycznymi teoriami feminizmu oraz queer studies, radykalną filozofią polityczną [...], socjologicznymi konceptualizacjami emocji, a także koncepcje podkreślające performatywny charakter współczesnych praktyk społeczno-kulturowych"6.

Moim zdaniem kategoria afektu wydaje się niezwykle interesująca, zwłaszcza $\mathrm{w}$ zestawieniu $\mathrm{z}$ teorią emocjonalności zaczerpniętą $\mathrm{z}$ epoki romantyzmu ${ }^{7}$, romantyczne uczucia czy afekty pozwalają bowiem dostrzec, że rzeczywistość jest w swojej istocie zmieszana i chaotyczna, że zupełnie jak współcześnie rozumiane afekty, jest „intensywnością, wirtu-

3 Zob. J. Flatley, Affective Mapping: Melancholia and the Politics of Modernism, Cambridge 2008, s. 12. Cyt. za: R. Sendyka, Nowe przestrzenie humanistyki: pamięć, afekty $i$ inne terytoria, [w:] Pamięć $i$ afekty, pod red. Z. Budrewicz, R. Sendyki, R. Nycza, Warszawa 2014, s. 17.

4 Tamże, s. 16.

${ }^{5}$ Wiele inspirujących odczytań tekstów literackich, fotografii, obrazów za pomocą pojęć zaczerpniętych z teorii afektu odnaleźć można w wydanej w 2014 roku książce Pamięć i afekty, red. Z. Budrewicz, R. Sendyka, R. Nycz, a także we wcześniejszych dwóch numerach „Tekstów Drugich” poświęconych tej tematyce: „Teksty Drugie” 2013 nr 6, Zaafektowani oraz „Teksty Drugie” 2014 nr 1, Afektywne manifesty.

6 M. Rosińska, Schizofreniczność afektu, „Kultura Współczesna” 2012, nr 3, s. 220, http://kulturawspolczesna.pl/archiwum/2012/3742012 (dostęp: 1.06.2015).

7 Brian Massumi pisał, że „afekt [...] to koncepcja, która pozwala wyjść poza ciało i jednocześnie zrozumieć zmieniające się wzajemnie relacje między różnymi ciałami (i w różnych układach: ciał ludzkich z nieludzkimi, nieludzkich z nieludzkimi itd.), obrazami (tak wytwarzanymi przez ludzi, jak i przez maszyny), narracjami”. Podobnie zresztą afekt pojmuje holenderska badaczka Mieke Bal, według której afekty pozwalają „analizować i poddawać krytyce trudne i złożone relacje między »wędrownymi pojęciami«, między reżimami produkcji wiedzy, między różnymi mediami, dyscyplinami, wreszcie między nauką i sztuką". Dlatego też wydaje się zasadne ukazywanie podobieństw i różnic w pojmowaniu afektów i emocji w dwóch oddalonych od siebie dłuższą perspektywą czasu epokach: romantyzmie i współczesności. Cyt. za: K. Bojarska, Poczuć myślenie: afektywne procedury historii i krytyki (dziś), „Teksty Drugie” 2013, nr 6, s. 10. 
alnością i potencjalnością"8, przestrzenią paradoksu, w której wystąpić moga „semantyczne inwersje, sprzeczne emocje”.

Możemy zaryzykować więc stwierdzenie, że romantyczna uczuciowość przywrócona zostaje współczesnej teorii za sprawą zwrotu afektywnego. Okazuje się ona tematem interesującym nie tylko dla teoretyków literatury, ale także pisarzy. Współcześni polscy poeci i prozaicy coraz częściej nawiązują bowiem w swojej twórczości do epoki romantyzmu, sięgając w pełni świadomie do jej dziedzictwa i ukazując, iż można wciąż odczytywać ją w zupełnie nowy, twórczy sposób ${ }^{10}$. Aby w pełni ukazać gre z romantycznym afektem we współczesnej prozie, zanalizuję przykład jednego z utworów polskiej literatury najnowszej, w którym gra z romantyzmem rozgrywa się na całkiem innym poziomie, dalekim od martyrologicznych konotacji11, zbliżając się raczej ku niezgłębionym jeszcze do końca kategoriom egzystencjalno-afektywnym.

Powieść Artura Daniela Liskowackiego Mariasz (2007), stanowiąca przedmiot tej analizy, dość wyraźnie spełnia postulat Agaty Bielik-Robson dotyczący odejścia od schematycznego odczytywania romantyzmu, a także podjęcia próby określanej przez Michała Kuziaka mianem „»romantyzacji« (po)nowoczesności”12. Sam Liskowacki poprzez stworzenie Mariasza staje się przedstawicielem generacji postromantyków ${ }^{13}$, ukaza-

8 Zob. B. Massumi, Autonomia afektu, „Teksty Drugie” 2013, nr 6, s. 111-134

${ }^{9}$ Afekty i nowoczesność, Instytut Badań Literackich Polskiej Akademii Nauk, <http: //ibl.waw.pl/pl/o-instytucie/pracownie-i-zespoly/zespol-do-badan-nad-literatura-i-kultura-p oznej-nowoczesnosci/afektyinowoczesnosc> (dostęp: 1.06.2015). Por. E. Van Alphen, Affective Operations of Art. and Literature, „RES” 2008, nr 53/54, s. 21-30; M. Bal, Czytanie sztuki?, „Teksty Drugie” 2012, nr 1-2; s. 39-57; B. Massumi, dz. cyt., s. 111-134; M. Rosińska, dz. cyt.

10 „Pisarze po 1989 r. zaczęli intensywnie penetrować podświadomość, sen, zło, chorobę, śmierć. Kreowali także obce nowoczesności, a charakterystyczne dla romantyzmu, obszary tajemnicy bytu, reaktywowali zapomniane, długo uważane za anachroniczne kategorie estetyczne: cudowności, fantazji, wzniosłości, melancholii”. Zob. M. Rabizo-Birek, Romantyczni i nowocześni. Formy obecności romantyzmu w polskiej literaturze wspótczesnej, Rzeszów 2012, s. 466.

$11 \mathrm{~W}$ eseju I rozważna i romantyczna... Bielik-Robson pisała: „Aby więc wydobyć z polskiego romantyzmu pierwiastek „wysoki”, należałoby odszukać w nim prób indywidualizacji; zignorować permanentne deklaracje natury wspólnotowej (jednostka-za-miliony) i skupić się na tym, co rzeczywiście indywidualne, anarchizujące i antytetyczne”. A. Bielik-Robson, I rozważna, i romantyczna - czyli o racjonalności romantyzmu, [w:] tejże, Romantyzm. Niedokończony projekt. Eseje, Kraków 2008, s. 6.

12 M. Kuziak, Romantyzm $i$ nowoczesność ? [w:] Romantyzm i nowoczesność, red. M. Kuziak, Kraków 2009, s. 7.

13 Zob. A. Bielik-Robson, My romantycy - źródła romantycznego modernizmu, [w:] Ch. Taylor, Źródta podmiotowości. Narodziny podmiotowości nowoczesnej. Oczywiście bez wątpienia ogromną rolę w kształtowaniu się wizji artystycznej Chwina odegrały seminaria 
ne bowiem w jego powieści dwie pozornie odległe historie prezentują kilka możliwych odczytań romantycznej teorii uczuć i dokładnie ukazują uważnemu czytelnikowi nieoczekiwane strony emocjonalności człowieka początku XXI wieku.

W powieści Liskowackiego romantyczna koncepcja mesmeryzmu i melancholii koresponduje $\mathrm{z}$ uczuciowością współczesnego bohatera. W pierwszych recenzjach pojawiających się po opublikowaniu Mariasza zwracano uwage przede wszystkim na oryginalny pomysł przedstawienia przeplatających się ze sobą dwóch, pozornie niemających ze sobą wiele wspólnego, opowieści. Pierwsza z nich to historia ostatnich lat życia Antoniego Malczewskiego, autora romantycznej powieści poetyckiej Maria. Druga z kolei to rozgrywająca się we współczesnych czasach opowieść o tajemniczej wakacyjnej przygodzie chłopca imieniem Muszka. Książka składa się z czterech części, które łączą liczne odwołania do Marii Malczewskiego - od charakterystycznego melancholijnego tonu powieści po skrajny pesymizm, cieleśnie wręcz odczuwaną pustkę, językowe niejednoznaczności i trudne do określenia relacje między bohaterami14. Tym, co łączy obie fabuły, jest także motyw gry w karty - bohaterowie rozgrywają partie nie tylko $\mathrm{w}$ toku akcji, ale także metaforycznie ${ }^{15}$, jakby całe ich życie było grą. Gra Malczewski - występujący w tekście jako M. - który „prowadzi grę $\mathrm{z}$ otoczeniem o akceptację i uznanie, o przezwyciężenie środowiskowej infamii"16. Gra także Muszka, którego jednocześnie fascy-

Marii Janion. Sam pisarz wspomina o tym w wywiadzie udzielonym Arkadiuszowi Bagłajewskiemu. Zob. O Hanemannie, tauromachii i trzech samobójstwach. Ze Stefanem Chwinem rozmawia Arkadiusz Bagłajewski, „Kresy” 1996, nr 25.

14 Marta Cuber dostrzega w Mariaszu „sąsiedztwo pogranicza geograficznego z pograniczem emocjonalnym (zakazana miłość na Kresach, niejednoznaczne przygody chłopięce na szczecińskim letnisku) oraz jej gorzka »chmurna«i bardzo elegijna tonacja. Rezygnacja, fatalność, której nikt nie zamierza przezwyciężyć, została jakby wprost przejęta z Marii, którą niegdyś jako tekst wyjątkowo melancholijny i nowoczesny czytał Marek Bieńczyk”. M. Cuber, Ot, i cała tajemnica, „Nowe Książki” 2007, nr 12.

15 Sam tytuł powieści rodzi możliwość wielu odczytań. Mariasz - to nazwa dawnej gry w karty, której zasady odnajdziemy na pierwszej stronie powieści. Cytując książkę Stanisława Kozietulskiego - Gry w karty dawne $i$ nowe $z 1888$ roku autor przypomina: „powodzenie w tej grze wymaga zastanowienia i zręczności [...], dobry gracz zwraca pilną uwagę na wytworzenie silnej karty pod koniec gry, kiedy się już kupka kart zapasowych wyczerpie i do maści oddawać potrzeba. Dlatego nie łakomiąc się na oczka tuzów i kralek oszczędza kozery na ostatek". Mariaż oznacza także mał̇eństwo, oraz - jak podaje Stownik języka polskiego - zwiazek czegoś z czymś lub kogoś z kimś. Tytuł powieści, zwłaszcza ze względu na postać Malczewskiego, kojarzy się z dziełem życia bohatera - powieścią poetycką Maria.

16 D. Nowacki, Gra zdobywcy Mont Blanc, „Gazeta Wyborcza” z dn. 9.10.2010, http://www.wforma.eu/-gra-zdobywcy-mont-blanc-gazeta-wyborcza-09102007,165.html (dostęp: 1.06.2015) 
nuje i przeraża tajemniczy Nieznajomy. Gra Zofia, która pragnie od M. coraz większej uwagi i bada granice jego wytrzymałości. Dlaczego bohaterowie grają? Z jednej strony dla zabicia czasu, przezwyciężenia wszechogarniającej nudy - nudy wiejskiego życia, nudy wakacji spędzonych nad Zalewem Szczecińskim, nudy jałowej egzystencji. Z drugiej strony natomiast poszukują oni w kartach nadziei na „odwrócenie losu, wygraną, mimo że wszystko już nieodwracalnie zostało stracone"17. Najciekawsze jednak w powieści Liskowackiego są gry uczuciowe, które prowadzone są między bohaterami na wielu płaszczyznach - intymnej, rodzinnej, metafizycznej. Zarówno M., jak i Muszka doznają podobnych uczuć pomimo dzielącego ich dystansu czasowego - doświadczają straty oraz wplątują się w niejednoznaczne związki, z których nie chcą lub nie próbują nawet się uwolnić. Jednakże te toksyczne relacje tworzą tożsamość bohaterów uświadamiają im ich (nie)przekraczalne granice.

\section{M(alczewski), Maria i mesmeryzm}

Interesowało mnie w tym życiorysie - Antoniego Malczewskiego - to, że był tak nieodpowiedzialny, a zarazem czytelny. Że miał miejsca puste, ciemne, i że one właśnie dlatego świeciły i domagały się wypełnienia... Co mnie urzekło w opowieści, według której opowiedziałem swojego „Mariasza”? Historia życiowej klęski. Której się M., czyli Malczewski [...] nie przeciwstawił. Czyżby dlatego, że nie umiał? Czy raczej dlatego, że nie chciał?18.

W taki właśnie sposób Liskowacki opowiada o bohaterze swojej powieści - M., którego bez trudu utożsamić możemy z osobą Antoniego Malczewskiego. Historia ostatnich lat życia przedstawiciela „polskiej szkoły ukraińskiej", autora Marii, w dziele Liskowackiego zostaje opowiedziana w porządku odwrotnym, przewrotnie - od końca, czyli od dnia śmierci poety 2 maja 1826 roku. Być może zabieg ten służyć ma zrozumieniu podejmowanych przez bohatera decyzji, jak chociażby trwania w toksycznym związku z Zofią Rucińską ${ }^{19}$. Nuda toczącego się na wsi życia wpędza

17 T. Mizerkiewicz, Magnetyczny punkt literatury, „Pogranicza” 2009, nr 6, s. 83.

18 M. Larek, Zdrada jest próba mistrza. Rozmowa $z$ Arturem Danielem Liskowackim, [w:] J. Borowczyk, M. Larek, Rozmowa była możliwa. Wywiady z pisarzami, Poznań 2008, s. $107-125$.

19 „Odwołując się do filozofii Emmanuela Lévinasa, stwierdzić można, że ewokacja w ciągu narracji zdarzeń, chronologicznie coraz bardziej oddalonych w przeszłości, jest $\mathrm{w}$ istocie hipostazą minionych chwil. Jakby autor poprzez formę swojej opowieści potwierdzić chciał zawarte $\mathrm{w}$ treści przypuszczenia, iż być może „im więcej ciebie nie ma, tym więcej ciebie jest”. Penetrując zdarzenia minione, zdolni jesteśmy uzyskać tylko złudzenie 
zdobywcę Mont Blanc w melancholijne wspomnienia czasu, a właściwie wydarzenia utraconego, kiedy to (jak pisał w Liście do profesora Picteta o zwiedzeniu jednej $z$ gór $w$ pobliżu Chammouni...) ${ }^{20}$ :

Zdaje się [...], że wszystko zdaje się zapowiadać tę chwilę. Wszystko zdaje się zapowiadać. Wszystko. Prawda jak ładnie. Powiedziane. Zapowiedziane, zapomniane. Wtedy wędrownik schodzi w dół, aby w ogromie przemian pochłonięty nie został. (M., s. 319) 11

Poeta jednak został przez owo wydarzenie pochłonięty, i to w pełni, gdyż całe jego życie od chwili zdobycia Mont Blanc naznaczone było poszukiwaniem podobnego, wstrząsającego, granicznego wydarzenia, które wytrąci M. z powtarzalności i nudy życia zwykłego śmiertelnika. Bohater powieści Liskowackiego ciągle czegoś szuka, ciągle odczuwa brak i niepewność. Spełnienia nie przynosi mu ani praca w ministerstwie, ani zarządzanie wiejskimi posiadłościami, ani twórczość poetycka. Jako poeta, wykreowany w powieści Liskowackiego bohater jest tak samo niezrozumiany jak sam Malczewski był w rzeczywistości. Michał, brat Rucińskiej, mimo literackich fascynacji nie rozumiał twórczości bohatera:

pewności co do ich istoty. Świat opisywany w czasie przeszłym już nie istnieje, w pamięci ludzkiej utrzymuje się tylko jego niewybrzmiały do końca pogłos. W tekście bezpośrednio wyraża te myśli M. w słowach: „Czyż nie jest tak, iż postępując krok, oddalamy się w istocie, a Wczoraj mądrzejsze jest od Jutra. Tak, że to, co zdaje się odkrywaniem dziś, jest tylko wspomnieniem, zblakłym, zatartym, które na bezradną pociechę, stawiamy przed sobą, jako nowe trofeum”. P. Rutkiewicz, Z poczatkiem od końca, „Tygiel Kultury” 2009, nr 7-9, s. 190-193.

20 „Malczewski, który odbywał podróż po Europie, zawitał latem 1818 roku do Genewy. Tu ujrzał Mont Blanc i wówczas podjął decyzję wejścia na szczyt. Nie zasłaniał się względami naukowymi, nie wysnuwał też na pierwszy plan czynników estetycznych. W opisie swej wyprawy stwierdził bez ogródek, że na szczyt popchnęły go «ciekawość i pochlebna chęć dokonania tych rzeczy, których na co dzień dopełnić nie można». Projektując swą wyprawę na Mont Blanc, Malczewski miał zamiar dokonać nawet czegoś większego aniżeli zdobycie szczytu znaną już drogą. Postanowił on wejść na niezdobytą wówczas Aiguille du Midi i stamtąd przejść na wierzchołek Mont Blanc”. „Taternik” 1968, nr 4, s. 155-157, http://pza.org.pl/download/taternik/315601.pdf> (dostęp: 19.06.2015). W 4. przypisie do Marii Malczewski opisał przeżycia ze zdobycia góry: „W podróży mojej na szczyt góry Mont-Blanc, gdzie przez dwie godziny pobytu doznawałem uczuć, jakich już zapewne w życiu swoim nie doświadczę. [...] Nic jednak wspanialszego i dzikszego, jak widok z góry Mont-Blanc [...], rzadkie powietrze i stąd krótki oddech i szybkie bicie pulsu, nadludzkim jakimś czuciem i uczuciem przejmują śmiertelnika”. A. Malczewski, Maria. Powieść ukraińska, wprow. H. Krukowska, J. Ławski, Białystok, s. 185.

21 Wszystkie cytaty z powieści Liskowackiego oznaczała będę w tekście głównym literą M., po której podam numer odpowiedniej strony. Wszystkie cytaty za: A.D. Liskowacki, Mariasz, Szczecin 2007. 
spłoszył go nieco mroczny ton tych wierszy, a przebijające z nich gorycz i żal raziły go jako zbyt ostentacyjne. Zwłaszcza, że dostrzegał w nich życiowe niepowodzenie samego M., takie zaś ukazywanie się światu zdało mu się trochę bezwstydne i małostkowe. (M., s. 140)

Słowa Michała brzmią niczym słowa krytyków, którzy nie docenili zupełnie odmiennej, mrocznej wizji romantyzmu proponowanej przez Malczewskiego. Jak przypomina Maria Żmigrodzka:

Malczewski był jedynym polskim poetą romantycznym, który nie wywodził się z doświadczeń poetyckich „Ballad i romansów” [...]. Samotność Malczewskiego, brak związków z kołami młodych romantyków i poparcia w kształtujących opinię czasopismach literackich, wyjaśniają już nie tylko niemożność zrozumienia nowatorskiego utworu przez szerszą publiczność literacką, ale i całkowite niemal milczenie wokół poematu pokwitowanego recenzenckimi złośliwościami Dmochowskiego, później zaś ogólnikowymi zachwytami Grabowskiego ${ }^{22}$.

Życie poety odmieniło poznanie Zofii Rucińskiej, kobiety schorowanej, o której dolegliwościach „mówiono jak o zamorskiej gorączce, nie biorąc na zbyt poważnie ani choroby, ani doktora" (M., s. 139). Z czasem okazuje się, że spazmatyczne ataki kobiety potrafi leczyć jedynie M., zapoznany ze sztuką modnego wówczas mesmeryzmu ${ }^{23}$. W toku akcji powieści do-

22 M. Żmigrodzka, Dwa oblicza wczesnego romantyzmu (Mickiewicz - Malczewski), „Pamiętnik Literacki” 1970, z. 1, s. 71-72.

23 „W Polsce zainteresowanie eksperymentami magnetyzerskimi oraz magnetyzmem jako nową teorią psychofizyczną oscylującą na granicy wiedzy tajemnej objawiło się w pierwszych dziesiątkach XIX w. przede wszystkim w Wilnie. Gorącym zwolennikiem i propagatorem wiedzy o magnetyzmie stał się I.E. Lachnicki, [...] [który] redagował w Wilnie czasopismo „Pamiętnik Magnetyczny” [...]. Van Helmont (lekarz i chemik flamandzki) „zdawał się wiązać zjawiska magnetyczne z dziedziną podświadomości, określając je jako przynależne do »krainy ciemnych wyobrażeń, uczuć, przeczuć i snów«, a w magnetyzmie widział »być może rzeczywiste objawienie tajemnicy sił przyrodzenia«, zbliżał się więc do romantyków niemieckich akcentujących nocną stronę bytu [...]. Mimo tych ataków ze strony kontynuatorów oświecenia magnetyzm cieszył się dość dużą popularnością w środowisku wileńskim, także wśród młodzieży akademickiej, i jak się wydaje, pozostawił pewne ślady w wyobraźni poetów romantycznych, którzy lata młodości spędzili w Wilnie". Mesmeryzm [hasło], [w:] Stownik literatury XIX wieku, red. J. Bachórz, A. Kowalczykowa, Wrocław 1991, s. 527.

Wątki mesmeryczne odnajdziemy także w Marii Malczewskiego: „Utwór przedstawia coś, co należałoby nazwać nie tyle nawet doświadczeniem, co doświadczaniem wzroku: ustawicznym badaniem jego różnych możliwości, różnych ustawień i kierunków patrzenia, zadawaniem mu różnych prób. Melancholia bowiem składnia się do patrzenia i jest uchwytna w Marii przede wszystkim jako modalność spojrzenia. Sposób działania i pozycja oka jest stałym motywem opisów [...]. To jakby nadobecność oka, furia, wzroku, ciągła świadomość patrzenia”. M. Bieńczyk, Wszystko w świecie tracić. ( $O$ „Marii” Antoniego Malczewskiego), [w:] tegoż, Oczy Dürera. O melancholii romantycznej, Warszawa 2002, s. 43. 
wiadujemy się, iż poeta zamieszkał w domu Rucińskiej i jej męża, pełniąc rolę stałego opiekuna, będącego na każde zawołanie kobiety. Przywołana w Mariaszu metoda magnetyzmu zdaje się jednak nie tylko oznaczać realną „terapię" jaką stosował na Rucińskiej poeta, lecz staje się ona także metaforą łączącej ich relacji opartej na oddziaływaniu osoby silniejszej na słabszą. Według ówczesnej mody magnetyzm uznawany był za metodę:

fizykalno-medyczną [...], której podstawą [...] oddziaływania miał być rzekomy „fluid” magnetyczny, „subtelny płyn” rozprzestrzeniony w całej przyrodzie. W przypadku człowieka oddziaływanie magnetyczne miało się dokonywać drogą emanacji fluidu skoncentrowanego uprzednio napięciem woli przez jednostkę o silniejszej osobowości i zdolnościach magnetyzerskich, a następnie skierowane ku drugiej osobie, zasadniczo w celach terapeutycznych. Magnetyzer leczaç przelewał w chorego ożywczą siłę poprzez przesuwanie rąk w niewielkiej odległości od ciała pacjenta, czyli tzw. pociągi lub pasy magnetyczne „patrząc przy tym z dzielnością" na magnetyzowanego ${ }^{24}$.

Magnetyzującym jest w powieści M. jako osobowość silniejsza, obdarzona „fluidem”, który uspokajał Zofię. Opisów magnetyzerskich „seansów" odnajdziemy w powieści Liskowackiego kilka:

Zofia odrzuciła nagle karty, sypnęły się na stół i podłogę, nadgarstkami ścisnęła skronie. Czekał na jej krzyk. Na to, że rozszlocha się i wyda z siebie ten zduszony jęk, przechodzący w skowytanie, miaukliwe zawodzenie, [...] te co go wszędzie odnajdywał, przenikał do trzewi, zmuszał do robienia tego wszystkiego, co tyle czasu czynił, a co od dawna już odbierało mu siły do robienia czegokolwiek. Ale trwała niemo, w bezruchu. Aż wreszcie w milczeniu opuściła ręce na stół, bez-

O prześmiewczo potraktowanym magnetyzmie w Ślubach panienskich Fredry pisał Mieczysław Inglot, Zob. M. Inglot, Wstęp, [w:] A. Fredro, Śluby panieńskie, czyli magnetyzm serca, oprac. M. Inglot, wyd. 5. zm., Wrocław 1972, BN I (22).

Wacław Borowy dowodził, że „[...] w literaturze magnetycznej znajdujemy szereg [...] wyobrażeń, które występują u Mickiewicza w związku z motywem "potężnego wzroku« [...]. O ile poskramianie, paraliżowanie ruchów za pomocą wzroku są to motywy bardzo pospolite, o tyle zabicie przez wzrok jest motywem wierzeniowym dość znanym. Magnetystom był on znany. [...] Konrad w Dziadach drezdeńskich nie tylko myśli przez chwilę, że może wzrokiem zabić, ale wierzy, że może zatrzymać w ruchu kometę. I to dziwne wierzenie ma analogię w literaturze magnetystów i dawnych mistyków, których oni rehabilitowali. Pierwsza rozprawa Mesmera była poświęcona związkowi człowieka z planetami i gwiazdami [...]. Wielorakie analogie z literatury magnetycznej i mistycznej wyjaśniają nam, że Konrad czuje w sobie moc magnetyczno-magiczną. Rozżarza się ona w «ognisku» uczucia, a narzędziem niejako uzewnętrzniającym ją jest wola [...], jednym zaś z organów woli jest oko: «oko bystre, potężne»". W. Borowy, „Potężne oko” Mickiewicza, [w:] tegoż, Kamienne rękawiczki $i$ inne studia $i$ szkice literackie, Warszawa 1932, s. 112.

24 Tamże, s. 526. 
władnie, wnętrzem dłoni do góry. Patrzył na te otwarte, białe muszle i nagle zapragnął złożyć na nich, w każdej z osobna cichy, głęboki pocałunek. Spokojny i mocny, jak odzyskany, znajomy smutek. Znalazła jego wzrok i zatrzymała go DŁUGIM, UWAŻNYM SPOJRZENIEM. (M., s. 31)

Tak jak pisałam wcześniej, relacja między Rucińską a Malczewskim w akcji powieści przekształca się stopniowo w coraz silniejsze przywiązanie, które z czasem, zwłaszcza ze strony Zofii, doprowadza do licznych scen. W przytoczonym fragmencie Zofia ulega co prawda wpływowi M. i uspokaja się, lecz jednak to ona zatrzymuje go „uważnym spojrzeniem”, tak jakby to kobieta, wbrew wcześniejszym założeniom, przejęła rolę magnetyzera i wpływała na bohatera swoją siłą. Przez histeryczne zachowania Rucińskiej M. nie może pracować, dlatego też rezygnuje z wszelkich zadań i decyduje się poświęcić kobiecie cały swój czas.

Malczewski darzy kobietę uczuciem, afektem trudnym do jednoznacznego opisania, balansującym na granicy namiętności i nienawiści:

Nie umiał sobie za to poradzić z dniami, gdy stan zdrowia Zofii wymagał niewychodzenia z domu. Cokolwiek wtedy robił, zdawało mu się to przyczajaniem bezczynności. A ta, zogromniała, niespodziewanie, wyłażąc z każdego kąta, każdego milczenia między nim a Zofią [...]. Wzdragał się, gdy wyobraźnia podsuwała mu obraz tej spoczywającej w puchach, sennej, uróżowionej ciepłem i bezwstydem, bo prócz obrzydzenia czuł też pokusę. Żeby w to łoże, to ciało, tę nicość wejść, zanurzyć się, zgubić, wyrzucić z siebie wszystko, wypuścić ostatnie soki, poddać się, zasnąć, spełniony i obojętny, daleki i bezpieczny. (M, s. 105)

M. z jednej strony ma żal do ukochanej, że ograniczyła jego wolność, $\mathrm{z}$ drugiej jednak nie potrafi zrezygnować $\mathrm{z}$ toksycznej relacji wtedy, kiedy jest jeszcze na to czas. Wmawia sobie, że ma kontrolę nad swoim życiem i w każdej chwili może wszystko w nim zmienić:

Cofnę się, zawrócę, myślał, a wszystko się wypełni. Jakbyś dół zasypał ziemią.

Zawsze coś wyrośnie, gorzkie ziele, trawa, róże czy cebula, krzyż albo dom. Cofnę się, zawrócę, a diabli będą mi bić brawo. (M., s. 235)

Gdy jednak zbliżają się momenty graniczne i decydujące, M. zdaje się wycofywać z życia, rezygnować z podjęcia ostatecznych decyzji, tak jak wcześniej, na szczycie Mont Blanc.

Analizując związek między bohaterami, należy zapytać: kto tak naprawdę wygrywa tę partię związkowego mariasza, kto jest katem, a kto ofiarą? Malczewski, który dzięki swoim magnetyzerskim zdolnościom potrafi zapanować nad chorobą Rucińskiej, czy Sophie, która swoim zachowaniem wymusza na bohaterze pewne reakcje? Zofia Rucińska już przez współczesnych przedstawiana była w negatywnym świetle jako 
kobieta fatalna, która doprowadziła do śmierci młodego poety. Ujejski w monografii Antoni Malczewski. Poeta i poemat przytacza relację Romana Załuskiego, współpracownika Malczewskiego, który twierdził, że Rucińska „nie mogąc znieść kilkugodzinnej co dzień nieobecności kochanka dręczyła go takimi skargami, w tak okropne wpadała konwulsje, ile razy odchodził z domu do biura - iż nieszczęśliwy Antoni musiał wypuścić chleb z ręki, aby w nędzy żyć tylko dla niej - i umrzeć!”25. Ten zaborczy rys charakteru kobiety zaznaczony zostaje wyraźnie w powieści Liskowackiego:

O DOTKNIĘCIACH ZIMNYCH JAK STAL, o świdrującym bólu, co ją przeszywał przy każdym ruchu, torturach knuta dręczących ciało na równi z duszą powtarzała mu nieustannie. Nawet, gdy próbował jej napomykać, że zaczęły wracać symptomy choroby, które miał już na Wołyniu, o których wówczas nie chciała słuchać lub przerywała mu i całowała po dłoniach z płaczem, by nie opuszczał jej, nie wybierał swojego cierpienia. (M., s. 36)

Postać Zofii w powieści nacechowana zostaje wyraźnie negatywnie. Jest ona kobietą narcystyczną i egoistyczną, pragnącą całkowitej uwagi ukochanego, nie troszczy się jednak o niego, gdy to on ciężko choruje. Nawet w chwili agonii Malczewskiego skupia się jedynie na swojej sytuacji, a zmęczone chorobą ciało ukochanego budzi w niej obrzydzenie:

Oddychał ciężko, poświstując mimo woli przez spierzchłe wargi. Tortury, jakby mnie żelazem rwali, Antoni, ja bez ciebie umrę. Powoli podniósł rękę, jakby chciał dotknąć jej ręki, biegnącej po krawędzi łóżka. Szukał jej dłoni rozczapierzonymi palcami. Jak pająk. Wzdrygnęła się i cofnęła swoją. (M., s. 23)

Alan Sasinowski określił związek bohaterów jako „twardy, szorstki, jak mokry powróz" 26 . W świecie przedstawionym podobną ocenę o tym związku wyraził brat Rucińskiej:

Bo M. i Sophie wydawali mu się czasem parą okrutnych, rozmiłowanych w swym okrucieństwie, kaleczących się z lubością upiorów. Jakby grali przeciw niemu $\mathrm{w}$ motię do spółki, w utrapieniu się zmieniając, cierpienie sobie pożyczając z trzymanego pospołu banku. (M., s. 24)

Ocena ta jest niezwykle trafna, ponieważ, analizując złożoną relację bohaterów, z łatwością dostrzeżemy, iż M. i Rucińska stanowią dla siebie zarazem szansę, jak i zagrożenie. Związek ten miał być dla obojga szansą

25 J. Ujejski, Antoni Malczewski. Poeta i poemat, Warszawa 1921, s. 263.

26 A. Sasinowski, Wodospad rzeczy, „Kurier Szczeciński” z dn. 24.10.2007, s. 171. http: //www.wforma.eu/-wodospad-rzeczy-kurier-szczecinski-24102007,166.html (dostęp: 1.06. 2015). 
na ciekawsze, bogatsze emocjonalnie życie, miał otwierać nowe perspektywy. Okazał się jednak pułapką, z której nie było wyjścia. Bohaterów połączyło poczucie bezsensu egzystencji, nie zostało one jednak w tejże relacji przezwyciężone. Miłość nie była w stanie ocalić ani Rucińskiej, ani Malczewskiego. Dodatkowo opisy ich wspólnego życia nie są nacechowane wzniosłością. Często pojawiają się fragmenty mówiące o wstręcie czy obrzydzeniu do ciała, życia i świata:

Pod chudą kołdrą czuł chłód ciągnący od ścian, tym większy, że ataki bólu, które złożyły go w łóżku, zraszały mu ciało potem, stygnącym teraz, po odejściu gorączki. Wydało mu się, że dzwonił zębami, ale szczęki zwarł mu zimny skurcz, jak psu, który nie może wypuścić zdławionej zdobyczy, i tylko w ich napięciu było przyczajone drżenie, bał się, że gdy poruszy głową, dzwonienie zębów zawładnie nim, rozdygocze mu całe ciało. Nie chciał tego, Wstydził się [...]. Dlatego, gdy z lękiem na twarzy, ze strachem przemieszanym z obrzydzeniem [...] nachylała się nad nim [...], uśmiechał się i wzrokiem mówił, że niczego mu nie trzeba. (M., s. 25)

Owa estetyka choroby, rozkładu, śmierci, którą tak często podkreśla w powieści Liskowacki, zbliżona jest do koncepcji świata przedstawionego Marii, w którym dostrzec można „bezgraniczny pesymizm i uderzający »bajronizm«", będące rodzajem „gestu kapitulacji Malczewskiego wobec zagadki świata [który] nie jest podyktowany jedynie przez względy moralistyczne czy wymogi konwencji tajemniczości narracji w powieści poetyckiej. Zło jest dla poety tajemnicą zarówno psychologiczną, jak i metafizyczną"27.

Zło i cierpienie, którym podlega bohater poematu - poeta, wpisują się także w koncepcję (post)romantycznego twórcy, którą przytacza Charles Taylor:

artysta jest osobą ofiarowującą nam epifanie, w których manifestuje się coś o wielkim moralnym lub duchowym znaczeniu - owa alternatywa sugeruje jedynie możliwość, iż to, co ujawniane, znajduje się poza sferą normalnie pojmowanej moralności oraz przeciwstawia się jej. Artysta jest istotą wyjątkową, zdolną do niezwykłych wizji; poeta jest obdarzony nadzwyczajną wrażliwością [...]. Dlatego właśnie artysta jest wyjątkowo podatny na cierpienie. Miało to częściowo wynikać z jego rzadkiej wrażliwości, która przynosi mu zarówno wielki ból, jak i wielką radość. [...] Odcięcie od możliwości zwyczajnego samospełnienia często oznacza także bycie odciętym od innych ludzi, życie na marginesie społeczeństwa, bycie niezrozumianym, pogardzanym ${ }^{28}$.

27 M. Żmigrodzka, dz. cyt., s. 85.

$28 \mathrm{Ch}$. Taylor, Wizje epoki postromantycznej, [w:] tegoż, Źródła podmiotowości. Narodziny tożsamości nowoczesnej, Warszawa 2001, s. 805-806. 
M. z powieści Liskowackiego wykreowany jest więc na romantycznego twórcę, który całym sobą odczuwa cierpienie otaczającego świata. Dodatkowo dręczy go świadomość niemożności pełnego spełnienia - nic nie jest w stanie powtórzyć afektu, jakiego doświadczył, zdobywając Mont Blanc. Miłość do Rucińskiej, zamiast do oczekiwanej pełni, doprowadziła do jeszcze większej alienacji, wycofania z życia społecznego i kulturalnego. Takie odczuwanie świata jako miejsca złowrogiego widoczne jest $\mathrm{w}$ jego poemacie, w którym, jak zauważa Halina Krukowska:

wszyscy bohaterowie [...] mają swą tajemnicza, „nocną stronę”; doświadczają ciemnych nastrojów i złowrogich przeczuć, będących echem świata zdominowanego przez nocny porządek istnienia. Czarny i straszny jest nie tylko świat zewnętrzny Malczewskiego, ale i świat wewnętrzny kreowanych przez niego postaci [...]. Tytułowa bohaterka poematu najsilniej odczuwa tajemne oddziaływanie niszczących mocy „drugiej strony”29.

Być może, akcentując właśnie tę emocjonalną stronę biografii Malczewskiego, Liskowacki pragnął wytłumaczyć wszechogarniający smutek Marii. Poemat ten zdaje się bowiem, w połączeniu z biografią poety, odpowiadać na zagadkę tajemniczego zła przenikającego zarówno Mariasz, jak i dzieło Malczewskiego. Zła, które pomimo że jest przyczyną cierpienia, sprawia pewien rodzaj perwersyjnej radości.

\section{Muszka, Nieznajomy i afekty}

Podobne do M. odczuwanie świata wyróżnia kolejnego bohatera powieści - Muszkę, młodego chłopca, który spędza nudne wakacje nad Zalewem Szczecińskim. Podobieństwo postaci wynika z odczuwanego przez chłopca poczucia melancholii. Muszka, tak jak M., tęskni, czuje brak brakuje mu miłości rodziców (ojciec nie interesuje się synem, matka - nazywana w powieści „ona” - woli spędzać czas z innymi mężczyznami), przyjaciół, przeżycia czegoś, co zmieni jego życie, wstrząśnie nim. Pomimo że opowieść o chłopcu toczy się w normalnym trybie - od początku do końca - to jednak sytuacje z poprzedniej opowieści, dotyczącej związku Malczewskiego i Rucińskiej, idealnie odpowiadają niejednoznacznej relacji łączącej Muszkę z Nieznajomym. Historia tej znajomości jest jakby odbiciem związku M. z Zofią. Nieznajomy, tak jak Rucińska, pojawia się w życiu bohatera niespodziewanie, jakby przez przypadek, jednak jego

${ }^{29} \mathrm{H}$. Krukowska, Ciemna strona istnienia $w$ romantycznym poemacie Malczewskiego, [w:] A. Malczewski, Maria. Powieść ukrainska, wprowadzenie: H. Krukowska, J. Ławski, Białystok 2012, s. 39. 
obecność daje Muszce szansę na przeżycie przygody. Pozwala mu oderwać się od szarej codzienności małego miasteczka, w którym de facto bohater nie ma przyjaciół. Jest tak samo samotny i niezrozumiany jak romantyczny poeta.

Muszka pewnego dnia podczas spaceru odkrywa kryjówkę, a w niej Nieznajomego - mężczyznę, który ukrywa się tam przed ludźmi. Czytelnik podejrzewa, że jest on przestępcą, świadczy o tym między innymi jego strój i styl bycia. Pierwsze spotkanie bohaterów, tak jak kolejne, naznaczone jest aurą niepokoju. Nieznajomy zastrasza chłopca, chce przejąć nad nim kontrolę, zapanować nad nim:

[...] poczuł równie raptowne, niespodziewane ukłucie. Pewność, że nie jest sam. Było to uczucie tak zaskakujące, że nie zdążył się nim naprawdę zaniepokoić. [...] Właśnie wtedy ktoś szarpnął nim, chwytając go wpół, zakrywając mu usta ręką. Poczuł mocną, drażniącą woń potu i twardy, piekący ucisk na szyi [...]. Mimo przerażenia pomyślał, że ostrze noża, jeżeli to nóż, jest ciepłe, jakby je ktoś długo ogrzewał w dłoniach. A zawsze czytał O DOTKNIĘCIACH ZIMNYCH JAK STAL. [...] Skąd on wiedział. Zagląda mi w myśli. Przez oczy. Niepotrzebnie. (M., s. 37)

Mężczyzna, wyczuwając strach Muszki, wymusza na nim za pomocą swej siły, nie tylko fizycznej, posłuszeństwo. Muszka od tej pory będzie pomagał Nieznajomemu - odwiedzał go, przynosił jedzenie - trochę ze strachu, trochę z powodu trudnej do określenia fascynacji (być może Nieznajomy odgrywa dla Muszki rolę ojca?). Pomoc Nieznajomemu bohater tłumaczy sobie chęcią odzyskania zegarka. Później uświadamia sobie jednak, że Nieznajomy nie chce mu go oddać, ponieważ wtedy straciłby jedyny punkt łączności z chłopcem:

Muszka czuł, że mężczyzna się waha [...], wolał żeby cokolwiek planował Nieznajomy nie było z jego powodu. Żeby nie miało z nim żadnego związku. A zarazem, zupełnie tego nie rozumiejąc, miał nadzieję, że tak właśnie jest. (M., s. 81)

Nieznajomy rozpoczyna z Muszką pewnego rodzaju grę opartą na połączeniu strachu i fascynacji. Chłopiec z jednej strony chce zerwać tę znajomość, z drugiej jednak czuje nieokreślone „przyciąganie” ze strony Nieznajomego (podobnie jak M. w stosunku do Zofii). Relacja bohaterów naznaczona jest tajemniczością. Muszka odczuwa obecność Nieznajomego w sposób zarówno cielesny (poprzez ocieranie się o niego, wąchanie go), jak i psychiczny (chłopiec odczuwa presję spełniania woli Nieznajomego, ale także myśli o nim w wolnych chwilach). Nieznajomy pragnie afektywnie zawładnąć Muszką:

Ja też cię będę widział, nachylił się, jakby tym szeptem chciał się wślizgnąć Muszce głęboko w ucho, choć wciąż jeszcze stali w pewnej odległości od siebie. 
Wystarczająco daleko, żeby szansę miał i ten, który chce odskoczyć, uciec, i ten, co chce pochwycić uciekającego. Będę cię widział cały czas. I cały czas będę obok. Muszka mijał Nieznajomego, nie patrząc na niego, ale tak blisko, że otarł się ramieniem o jego łokieć. Zgaszona już woń ostrego potu, a z nią inna [...] owionęły Muszkę, przebijając się przez smród znad dołu, jakby się chciały przylepić do jego ubrania, skóry. I wyjść stąd z nim, w nim. Wzdrygnął się. (M., s. 81)

Opisy spotkań z Nieznajomym są niezwykle sensualne. Jak zaznacza Paweł Tomczok,

W całej powieści wiele miejsca poświęca się fizjologii, cielesności bohaterów, odczuciom zmysłowym. Narrator lubuje się w opisach ciała zlanego potem, moczem i spermą, śmierdzącego dymem, zgnilizną, często poharatanego i krwawiącego ${ }^{30}$.

Cielesność i brzydota w części dotyczącej Malczewskiego zaznaczone były delikatniej, w opisie relacji Muszki i Nieznajomego stają się podstawą opisu. Postać Nieznajomego, który ociera się, narzuca swoją obecność nie tylko słowami, ale i zapachem, wzbudza w Muszce uczucie wstrętu ${ }^{31}$. Julia Kristeva w Potędze obrzydzenia pisała, że

we wstręcie przejawia się jeden z owych gwałtownych i mrocznych buntów bytu przeciw temu, co mu zagraża i co, jak się zdaje, nadchodzi z zewnątrz lub rozsadza od wewnątrz, rzucone obok tego, co dopuszczalne, tolerowane, możliwe do pomyślenia. [...] Wstręt, to niewątpliwie granica, lecz przede wszystkim wstręt jest dwuznaczny. Co prawda wyznacza podmiot, lecz nie oddziela go radykalnie od tego, co mu zagraża - przeciwnie, ujawnia że podmiot jest w ciągłym niebezpieczeństwie. Ale przecież wstręt sam jest z kolei mieszanką osądu i afektu, wyroku i szczerości, znaków i popędów [...]. To polecenie, to spojrzenie, ten głos, ten gest, które ustanawiają prawo do mojego zlęknionego ciała, tworzą i wywołują afekt, jeszcze nie znak. Afekt ten zwracam gdzieś zupełnie bez celu, żeby wykluczyć go z tego, co odtąd będzie dla mnie światem niemożliwym do przyswojenia. [...] Odczuwam wstręt tylko wtedy, gdy Inny umościł się na miejscu i w punkcie tego, co będzie „mną”. To nie inny, z którym się utożsamiam, ani którego wchłaniam, lecz Inny, który mnie poprzedza i bierze mnie w posiadanie, a przez to posiadanie sprawia, że jestem ${ }^{32}$.

30 P. Tomczok, dz. cyt., s. 165.

31 B. Massumi w tekście Autonomia afektu wielokrotnie zaznaczał, że „Afekt ma bowiem charakter synestetyczny, ponieważ wiąże się z udziałem poszczególnych zmysłów w sobie nawzajem: miarą potencjalnych interakcji jakiejś rzeczy żywej jest jej zdolność do przekształcania efektów jednego trybu zmysłowego w efekty innego trybu (dotyk i wzrok to najbardziej oczywiste, lecz bynajmniej nie jedyne przykłady)”. B. Massumi, Autonomia afektu, „Teksty Drugie” 2013, nr 6, s. 123.

32 J. Kristeva, Potęga obrzydzenia. Esej o wstręcie, przeł. M. Falski, Kraków 2007, s. $7-16$. 
Relacja Muszki z Nieznajomym jest połączeniem wymienionych przez Kristevę afektów: strachu i wstydu, które jednocześnie budzą w bohaterze chęć dalszego poznania. Nieznajomy go fascynuje, bo jest Innym, kimś, kto wyraźnie zaznacza swoją odrębność i oryginalność. Muszka nie potrafi zerwać niejednoznacznej relacji z Nieznajomym, tak jak Malczewski nie potrafił odejść od wampirycznej ukochanej.

Muszkę łączy z mężczyzną także specyficzny stosunek emocjonalny. O ile w przypadku Malczewskiego i Rucińskiej odwoływałam się do koncepcji mesmeryzmu, by ukazać wzajemne oddziaływanie bohaterów na siebie, tak w przypadku Muszki i Nieznajomego sięgnę do teorii afektu Ernsta van Alphena, który przypomina, iż:

\begin{abstract}
Afekty wytwarzają się w interakcji z przedmiotem, środowiskiem, drugim człowiekiem. [...]. Osoba, która otrzymała i przyjęła afekt, musi się do niego ustosunkować. Może „wyrzucić” go na zewnątrz lub też zatrzymać w sobie [...]. Jeżeli osoba, w kierunku której afekt został przetransmitowany, nie „zaprojektuje” afektu skierowanego na zewnątrz, lecz „wychwyci” go, możemy wtedy mówić o nadaniu mu odpowiedniej treści. Afekt określony przez osobę staje się uczuciem, takim jak: smutek, złość, niepokój. Droga afektu zakłada różnice w jego odczytaniu, które mogą zachodzić w czasie jego transmisji od jednej do drugiej osoby [...]. Transmitowanie afektu między jedną a drugą osobą może sprawić, że osoby te staną się do siebie podobne, np. smutek czy depresja jednej osoby może powodować taki sam stan u osoby kolejnej. Taka forma transmisji zostaje nazwana „porwaniem” przez afekt, wciągnięciem w dany stan. Oczywiście może się też zdarzyć, że w wyniku takiej transmisji dana osoba przyjmie stanowisko zupełnie przeciwstawne, np. depresyjne zachowania danej osoby wzbudzą w partnerze rozmowy uczucie gniewu ${ }^{33}$.
\end{abstract}

Nieznajomy, oddziałując na Muszkę swoją brutalnością, chce wzbudzić $\mathrm{w}$ nim strach, chce, by chłopiec mu się podporządkował i spełniał jego żądania. Muszka jednak, choć początkowo jest przerażony osobą Nieznajomego, z czasem odkrywa jego liczne wady, a także kierujące nim uczucie strachu przed odnalezieniem. Możemy powiedzieć, że chłopiec, zgodnie z teorią Alphena, „wychwytuje” otrzymany od Nieznajomego afekt i nadaje mu odpowiednią treść. Odkrywa bowiem słabe punkty Nieznajomego, co budzi nieznane dotąd poczucie dominacji. Punktem zwrotnym powieści jest moment, gdy bohater uświadamia sobie, że: ,jest całkiem inaczej, zupełnie na odwrót. To nie tamten widzi i wie. To on. Muszka. Więcej niż wie. Samym chceniem" (M., s. 197). Uświadomienie sobie własnej siły zmienia relację między bohaterami. Od tej pory Muszka czuje się pewniej w otoczeniu Nieznajomego i przebywa z nim nie

${ }^{33}$ E. van Alphen, dz. cyt., s. 21-30. 
z powodu strachu, ale dlatego, że sprawia mu to pewnego rodzaju przyjemność. Od tego momentu to Muszka rozdaje karty, czego świadectwem jest wskazanie policjantom kryjówki Nieznajomego (co później sam bohater utożsamia ze zdradą).

Warto przyjrzeć się bliżej postaci Muszki. W jednym z wywiadów Liskowacki na pytanie o „pierwiastek dziecięcy” w literaturze odpowiedział:

użyłbym pewnie takich słów, jak tęsknota, oczekiwanie, nadzieja, obietnica. Dziecko ma nadzieję na wszystko. Ale czuje też strach. Strach jest kulturowo podszyty tworzeniem. A ono zaczyna się od lęku, niepokoju, zaklinania grozy ${ }^{34}$.

Zdaje się, że przytoczone powyżej przez Liskowackiego emocje i afekty budują tożsamość Muszki. Bohater, chociaż ma cechy dziecięce, ma w sobie dużą dozę dorosłości - w powieści często określany jest słowami „stary-maleńki”. Chłopiec ma niezwykle rozwiniętą, jak na młody wiek, zdolność do oceny świata. Z powodu swego niejednoznacznego statusu przypomina Pacholę z poematu Malczewskiego ${ }^{35}$.

Muszka, pomimo swej dziecięcej niepozorności, decyduje się na gest wydania osoby, z którą nawiązał bliską relację - dokonuje pewnego rodzaju zdrady na najbliższej mu (choć niebezpiecznej) osobie. Pożegnanie Muszki z miejscem wakacyjnej przygody jest niezwykle emocjonalne. Opuszczając je, bohater puka w ściany - taki sam gest pożegnania uczynił Nieznajomy. Emocje nie pozwalają mu się wypowiedzieć: „w gardle ciągnęło i dławiło, jakby połknął gumę do żucia. Ale nie bolało. Nie bolało. Nie". (M., s. 316). Jest to moment szczytowy powieści, rodzaj symbolicznego pożegnania wspomnienia dzieciństwa. Płacz Muszki możemy odczytać $\mathrm{z}$ jednej strony jako wynik smutku, z drugiej natomiast jako reakcję na spotkanie bohatera ze spełnieniem, dotarciem do pewnej pełni i do pewnej granicy.

Mariasz Liskowackiego bardzo wyraźnie ukazuje czytelnikowi, w jaki sposób romantyczna koncepcja mesmeryzmu i melancholii koresponduje z uczuciowością współczesnego człowieka. W powieści dwa pozornie niezwiązane ze sobą wątki łączy melancholijny ton, w którym pobrzmiewają echa romantycznej Marii Malczewskiego. Zarówno M., jak i Muszka doznają podobnych uczuć pomimo dzielącego ich dystansu czasowego doświadczają straty, która odzwierciedla się w określającej ich melancholii, oraz wplątują się w niejednoznaczne związki, z których nie chcą lub

34 M. Larek, dz. cyt., s. 107-125.

35 „Pacholę u Malczewskiego jest postacią najbardziej tajemniczą, najdziwniejszą, obudowaną setkami interpretacji. [...] Ta jego podwójność, wieloznaczność. Z jednej strony dziecko, z drugiej dorosły. Z jednej strony autor, z drugiej jego kreacja, ofiara. Niewinność bywa przerażająca, bo w niej się kryją najgłębsze otchłanie”. Tamże, s. 123. 
nie próbują się nawet uwolnić. Okazuje się zatem, iż zaczerpnięte z epoki romantyzmu teorie uczuciowości mogą wybrzmieć w nowy sposób we współczesnej prozie, która chętnie powraca do niemartyrologicznego dziedzictwa tej właśnie epoki. Współczesna teoria afektu pomaga w pełny, bardziej klarowny sposób, opisać niejednoznaczną sieć powiązań między bohaterami, a także dostrzec, iż pomimo dzielacego bohaterów dystansu czasowego przeżywają oni afekty niezwykle podobne, mimo że inaczej opisywane. Romantyczna, tajemnicza siła mesmeryzmu, działa równie wyraźnie w relacji Muszki i Nieznajomego jak i M. i Zofii. Obu bohaterów łączy także romantyczne pojęcie melancholii, którą to możemy uznać za jedną z głównych przyczyn, dla których decydują się na niebezpieczne relacje, która pozwalają im w pełni doświadczyć silnych, afektywnych przeżyć i określić własne, nieprzekraczalne granice.

\section{BIBLIOGRAFIA}

Alphen E. van, Affective Operations of Art. and Literature, "RES" 2008, nr 53/54, s. 21-30, http://folk.uib.no/hlils/TBLR-B/Alphen.pdf (dostęp: 1 czerwca 2015).

Bal M., Czytanie sztuki?, „Teksty Drugie” 2012, nr 1-2; s. 39-57.

Bielik-Robson A., I rozważna $i$ romantyczna - czyli o racjonalności romantyzmu, [w:] A. Bielik-Robson, Romantyzm. Niedokończony projekt. Eseje, Kraków 2008, s. $6-18$.

Bielik-Robson A., My romantycy - źródła romantycznego modernizmu, [w:] Ch. Taylor, Źródta podmiotowości. Narodziny podmiotowości nowoczesnej, Warszawa 2001.

Bieńczyk M., Wszystko w świecie tracić. (O „Marii” Antoniego Malczewskiego), [w:] M. Bieńczyk, Oczy Dürera. O melancholii romantycznej, Warszawa 2002, s. 37-56.

Bojarska K., Poczuć myślenie: afektywne procedury historii i krytyki (dziś), „Teksty Drugie” 2013, nr 6, s. 8-16.

Borowy W., „Potężne oko” Mickiewicza, [w:] W. Borowy, Kamienne rękawiczki i inne studia $i$ szkice literackie, Warszawa 1932.

Chwaściński B., Narodziny alpinizmu polskiego, „Taternik” 1968, nr 4, s. 154-158, http://pza.org.pl/download/taternik/315601.pdf (dostęp: 19.06.2015).

Cuber M., Ot, i cała tajemnica, „Nowe Książki” 2007, nr 12, http://www.wforma.eu/ot-i-cala-tajemnica-nowe-ksiazki-12-2007,171.html (dostęp: 1.06.2015).

Emocje w kulturze, red. M. Rajtar, J. Straczuk, Warszawa 2012.

Flatley J., Affective Mapping: Melancholia and the Politics of Modernism, Cambridge 2008.

Inglot M., Wstęp, [w:] A. Fredro, Śluby panieńskie, czyli magnetyzm serca, oprac. M. Inglot, wyd. 5 zm., Wrocław 1972, BN I (22).

Kristeva J., Potęga obrzydzenia. Esej o wstręcie, przeł. M. Falski, Kraków 2007. 
Krukowska H., Ciemna strona istnienia $w$ romantycznym poemacie Malczewskiego, [w:] A. Malczewski, Maria. Powieść ukraińska, wprowadzenie: H. Krukowska, J. Ławski, wyd. 2, Białystok 2012, s. 7-70.

Kuziak M., Romantyzm i nowoczesność?, [w:] Romantyzm i nowoczesność, red. M. Kuziak, Kraków 2009, s. 5-13.

Larek M., Zdrada jest próbą mistrza. Rozmowa z Arturem Danielem Liskowackim, [w:] J. Borowczyk, M. Larek, Rozmowa była możliwa. Wywiady z pisarzami, Poznań 2008, s. 107-125.

Liskowacki A.D., Mariasz, Szczecin 2007.

Massumi B., Autonomia afektu, „Teksty Drugie” 2013, nr 6, s. 111-134.

Mizerkiewicz T., Magnetyczny punkt literatury, „Pogranicza” 2009, nr 6, http://www. wforma.eu/-magnetyczny-punkt-literatury-pogranicza-6-2007,176.html (dostęp: 1.06.2015).

Nowacki D., Gra zdobywcy Mont Blanc, „Gazeta Wyborcza” z dn. 9.10.2010, http:// www.wforma.eu/-gra-zdobywcy-mont-blanc-gazeta-wyborcza-09102007,165.html (dostęp: 1.06.2015).

Rabizo-Birek M., Romantyczni i nowocześni. Formy obecności romantyzmu w polskiej literaturze współczesnej, Rzeszów 2012.

Rosińska M., Schizofreniczność afektu, „Kultura Współczesna” 2012, nr 3, s. 220, http://kulturawspolczesna.pl/archiwum/2012/3742012 (dostęp: 1.06.2015).

Rutkiewicz P., Z poczatkiem od końca, „Tygiel Kultury” 2009, nr 7-9, s. 190-193.

Sasinowski A., Wodospad rzeczy, „Kurier Szczeciński” z dn. 24.10.2007, http://www.wf orma.eu/-wodospad-rzeczy-kurier-szczecinski-24102007,166.html (dostęp: 1.06. 2015)

Sendyka R., Nowe przestrzenie humanistyki: pamięć, afekty i inne terytoria, [w:] Pamięć i afekty, red. Z. Budrewicz, R. Sendyka, R. Nycz, Warszawa 2014, s. 15.

Taylor Ch., Wizje epoki postromantycznej, [w:] Ch. Taylor, Źródta podmiotowości. Narodziny tożsamości nowoczesnej, Warszawa 2001, s. 772-836.

Ujejski J., Antoni Malczewski. Poeta i poemat, Warszawa 1921.

Żmigrodzka M., Dwa oblicza wczesnego romantyzmu (Mickiewicz - Malczewski), „Pamiętnik Literacki” 1970, z. 1, s. 70-88. 